\title{
Systemic Literature Review of the Use of Virtual Reality for Rehabilitation in Parkinson Disease
}

\author{
Brian Chau, MD; Sarah Humbert, MD; and Aaron Shou, MD
}

Background: Functional rehabilitation is important when managing Parkinson disease (PD). Virtual reality (VR) therapy is a noninvasive, potential alternative or adjunct to conventional therapies used during rehabilitation.

Observations: The authors searched for articles in Google Scholar, PubMed, Physiotherapy Evidence Database Score (PEDro), and Cochrane after setting specific requirements starting in July 2019. Methodologic quality was assessed by PEDro for randomized controlled trials. Among 89 studies identified, 28 included in this review evaluated VR therapy for use during rehabilitation for PD: 7 used immersive VR and 21 used nonimmersive VR. Among the immersive
VR studies, 6 showed improvement in primary outcomes after adding VR therapy. Among the nonimmersive VR studies, 5 showed improvement with VR therapy when compared with conventional therapy, 9 showed improvement with VR and conventional therapy with no between group difference, and the remaining 7 showed improvement in primary outcomes after adding VR intervention. The quality and diversity of studies was a major limitation.

Conclusion: VR therapy is a promising rehabilitation modality for PD but more studies are needed. Additional investigations of VR therapy and PD should include direct comparisons between immersive and nonimmersive VR therapies.
Author affiliations can be found at the end of the article.

Correspondence:

Aaron Shou

(aarontshou@gmail.com)

Fed Pract. 2021;38(suppl 1). Published online

April 12, 2021.

doi:10.12788/fp. 0112
$\mathrm{P}$ arkinson disease (PD) is the second most common neurodegenerative disorder after Alzheimer disease. ${ }^{1}$ Age-standardized incidence rates of PD in population-based studies in Europe and the United States range from 8.6 to 19.0 per 100,000 individuals, using a strict diagnostic criterion for $\mathrm{PD} .^{2}$ The negative impact of $P D$ on health-related quality of life imposes a heavy burden on veterans. According to the US Department of Veterans Affairs (VA) National Parkinson's Disease Consortium, the VA has as many as 50,000 patients with PD under its care. Because of this demand, the VA has strived to revolutionize available services for veterans with PD and related movement disorders. ${ }^{3}$

The classic motor symptoms of resting tremors, bradykinesia, postural instability, and rigidity of this progressive neurodegenerative disorder is a significant cause of functional limitations that lead to increased falls and inability to perform activities of daily living that challenges the individual and caregiver. ${ }^{4}$ Rehabilitation has been considered as an adjuvant to surgical and medical treatments for PD to maximize function and minimize complications. High-intensity multimodal exercise boot camps and therapy that focuses on intensely exercising high-amplitude movements, have been shown to improve motor performance in PD. ${ }^{5,6}$ Available evidence has shown that exercise-dependent plasticity is the main mechanism underlying the effects of physiotherapy because it increases synaptic strength and affects neurotransmission. ${ }^{7}$ Although there is no consensus on the optimal approach for rehabilitation, innovative techniques have been proposed and studied. One such approach involves virtual reality (VR), which has begun to attract attention for its potential use during rehabilitation. ${ }^{8}$

VR is a simulated experience created by computer-based technology that grants users access to a virtual environment. There are 2 categories of VR: immersive and nonimmersive. Immersive VR is the most direct experience of virtual environments and usually is implemented through a head-mounted display. These displays have monitors in front of each eye, which can provide monocular or biocular imaging with the most common display being small liquid crystal display (LCD) panels.

Nonimmersive VR typically allows a participant to view a virtual environment by using standard high-resolution monitors rather than a headset or an immersive screen room. Many systems are readily available to the general public as electronic interactive entertainment (ie, video games). Interaction with the virtual world happens through interfaces such as keyboards and controllers while viewing a television or computer monitor. These systems often are more accessible and affordable when compared with immersive VR, although this is changing rapidly.

VR therapy is a noninvasive therapeutic alternative modality for PD. This review aims to study the use of VR to treat PD from a rehabilitative standpoint. Although not the only review on the topic, this systematic review is the first 
to examine the differences between immersive and nonimmersive VR rehabilitation for PD. VR technology is evolving rapidly and the research behind its clinical applications is steadily growing, especially as accessibility improves. This review also is an updated summary of the current literature on the effectiveness of VR therapy during PD rehabilitation.

\section{METHODS}

Starting in July 2019, the authors searched several databases (PubMed, Google Scholar, Cochrane, and the Physiotherapy Evidence Database [PEDro]) for articles by using the keyword "Parkinson's disease" combined with either "virtual reality" or "video games." To find studies specific to rehabilitation, searches included the additional keyword: "rehabilitation." After compiling an initial set of 89 articles, titles were reviewed to eliminate duplicates. The authors then read the abstracts to exclude study protocols, systematic reviews, and studies that used VR but did not focus on PD or any therapeutic outcome.

Articles were sorted into immersive or nonimmersive virtual reality categories. To be included as immersive VR, studies had to use any type of VR headset or full-scale VR room. Anything less immersive or similar to a traditional video game was included in the nonimmersive VR category. Articles that met inclusion criteria were selected for the systematic review. Criteria for inclusion in this review were: (1) English language; (2) included a study population focused on PD; (3) used some form of VR therapy; and (4) assessed potential rehabilitation by quantitative outcome measures. Only articles published in peer-reviewed journals were included.

Data were extracted into 2 tables specifically modified for this review: immersive and nonimmersive VR. Extracted data included study author name and publication date, study design, methodologic quality, sample size and group allocation, symptom progression via the Hoehn and Yahr Scale (1 to 5), VR modality, presence of control groups, primary outcomes, and primary findings.

Two of the authors (AS, BC) assessed the quality of each study by using the 11-point PEDro scale for randomized controlled trials (RCTs) (Table 1). Most criterion relate to the design and conduct of the study, but 3 focus on eligibility criteria (item 1), between-group statistical comparisons (item 10), and measures of vari-
TABLE 1 Physiotherapy Evidence Database Scale Elements

\begin{tabular}{|c|c|}
\hline Items & Descriptions \\
\hline 1 & Eligibility criteria specified ${ }^{a}$ \\
\hline 2 & Subjects randomly allocated to groups \\
\hline 3 & Allocation concealed \\
\hline 4 & $\begin{array}{l}\text { The groups similar at baseline regarding the most important prognostic } \\
\text { indicators }\end{array}$ \\
\hline 5 & Blinding of all subjects \\
\hline 6 & Blinding of all therapists administering therapy \\
\hline 7 & Blinding of all assessors who measured $\geq 1$ key outcome \\
\hline 8 & $\begin{array}{l}\text { Measures of } \geq 1 \text { key outcome obtained from }>85 \% \text { of subjects initially } \\
\text { allocated to groups }\end{array}$ \\
\hline 9 & $\begin{array}{l}\text { All subjects with available outcome measures received treatment or } \\
\text { control condition as allocated or, data for } \geq 1 \text { key outcome was analyzed } \\
\text { by intention to treat }\end{array}$ \\
\hline 10 & Between-group statistical comparison results reported for $\geq 1$ key outcome \\
\hline 11 & Both point measures and measures of variability provided for $\geq 1$ key outcome \\
\hline
\end{tabular}

ability (item 11). The total possible score was 10 because only 2 out of the 3 items on reporting quality contributed points to the total score (eligibility criteria specified did not). ${ }^{9}$

\section{RESULTS}

This review is reported according to Preferred Reporting Items for Systematic Reviews and Meta-Analyses guidelines (PRISMA). ${ }^{10}$ After screening and assessment, 28 articles met inclusion criteria for this review: 7 using immersive VR and 21 using nonimmersive VR (Figure). The immersive studies included 2 RCTs (both with PEDro scores of 5), 1 controlled study with a PEDro score of 5,1 prepost pilot study, and 3 cohort studies (Table 2). The nonimmersive studies included 13 RCTs with an average PEDro score of 5.8 ; 2 pre-post pilot studies, 1 repeated measures study with a historic control, 1 non-RCT, 2 pre-post prospective studies, and 2 cohort studies (1 retrospective and 1 prospective) (Table 3).

Several outcome and assessment tools were used; the most common measures were related to gait, balance, kinematics, and VR feasibility. Studies varied in VR modalities and protocol, 
TABLE 2 Immersive Virtual Reality Studies

\begin{tabular}{|c|c|c|c|c|c|}
\hline $\begin{array}{l}\text { Source } \\
\text { Study design } \\
\text { (PEDro score) }\end{array}$ & $\begin{array}{l}\text { Participants, No. } \\
\text { (H\&Y) } \\
\text { Study Groups: No. }\end{array}$ & VR Modality and Duration & Control & Outcomes & Primary Findings \\
\hline $\begin{array}{l}\text { Janeh et al, } \\
2019^{11} \\
\text { Pre/post pilot }\end{array}$ & $15(2-3)$ & $\begin{array}{l}\text { Unity3D with GAITRite } \\
\text { electronic walkway system; } \\
\text { HTC Vive headset }\end{array}$ & $\begin{array}{l}\text { Same } \\
\text { procedure } \\
\text { without VR }\end{array}$ & $\begin{array}{l}\text { Spatio-temporal } \\
\text { gait parameters via } \\
\text { GAITRite walkway } \\
\text { system }\end{array}$ & $\begin{array}{l}\text { VR manipulation tasks } \\
\text { significantly increased step width } \\
\text { and swing time variability for } \\
\text { both body sides; there was no } \\
\text { carryover after VR }\end{array}$ \\
\hline $\begin{array}{l}\text { Ma et al, } 2011^{12} \\
\operatorname{RCT}(5)\end{array}$ & $\begin{array}{l}33(2-3) \\
\text { Control: } 16 \\
\text { Experimental: } 17\end{array}$ & $\begin{array}{l}\text { Polarized glasses plus } \\
\text { projection-based VR } \\
\text { system with motion track- } \\
\text { ing; } 60 \text { trials of reaching } \\
\text { for fast-moving virtual balls } \\
\text { with dominant hand }\end{array}$ & $\begin{array}{l}60 \text { trials } \\
\text { turning } \\
\text { pegs with } \\
\text { nondomi- } \\
\text { nant hand }\end{array}$ & $\begin{array}{l}\text { Success rates and } \\
\text { kinematic data }\end{array}$ & $\begin{array}{l}\text { VR group became faster and } \\
\text { more forceful when reaching for } \\
\text { stationary balls; no significant } \\
\text { difference in success rate or } \\
\text { kinematics with moving balls }\end{array}$ \\
\hline $\begin{array}{l}\text { Robles-Garcia } \\
\text { et al, } 2016^{13} \\
\text { RCT (5) }\end{array}$ & $\begin{array}{l}16 \\
\text { Control: } 8 \\
\text { Experimental: } 8\end{array}$ & $\begin{array}{l}\text { VR avatar via head } \\
\text { mounted display; } \\
\text { three } 25 \text { to } 35 \text { min- } \\
\text { sessions/wk for } 4 \text { wks }\end{array}$ & $\begin{array}{l}\text { Same VR } \\
\text { system, } \\
\text { but lacked } \\
\text { imitation }\end{array}$ & $\begin{array}{l}\text { Self-paced } \\
\text { movement features } \\
\text { and cortico-spinal } \\
\text { excitability }\end{array}$ & $\begin{array}{l}\text { Movement amplitude } \\
\text { increased significantly in the } \\
\text { experimental group }\end{array}$ \\
\hline $\begin{array}{l}\text { Ma et al, } 2012^{35} \\
\text { Controlled }(5)\end{array}$ & $\begin{array}{l}24(1-3) \\
\text { Control: } 24 \\
\text { without PD } \\
\text { Experimental: } 24\end{array}$ & $\begin{array}{l}\text { Polarized glasses plus } \\
\text { projection-based VR } \\
\text { system with motion } \\
\text { tracking; } 5 \text { trials of both } \\
\text { physical and virtual reality }\end{array}$ & $\begin{array}{l}\text { Physical } \\
\text { reality }\end{array}$ & $\begin{array}{l}\text { Trunk and arm } \\
\text { movement times, } \\
\text { trunk-arm } \\
\text { coordination, index- } \\
\text { desynchrony score }\end{array}$ & $\begin{array}{l}\text { VR induced shorter trunk MTs, } \\
\text { shorter offset intervals, and } \\
\text { lower desynchrony scores }\end{array}$ \\
\hline $\begin{array}{l}\text { Griffin et al, } \\
2011^{36} \\
\text { Repeated } \\
\text { measure cohort }\end{array}$ & $26(2-4)$ & $\begin{array}{l}\text { VRG (might be more con- } \\
\text { sistent with augmented } \\
\text { reality glasses; unable } \\
\text { to confirm specifics of } \\
\text { glasses) }\end{array}$ & $\begin{array}{l}\text { Same } \\
\text { procedure } \\
\text { without VR }\end{array}$ & $\begin{array}{l}\text { Task completion } \\
\text { time, gait, FoG } \\
\text { frequency; FoF }\end{array}$ & $\begin{array}{l}\text { Only visual-flow VRG stimuli } \\
\text { showed improvement in task } \\
\text { completion time; VRG rhythmic } \\
\text { cueing impaired overall walking }\end{array}$ \\
\hline $\begin{array}{l}\text { Espay et al, } \\
2010^{37} \\
\text { Prospective } \\
\text { cohort } \\
\text { crossover }\end{array}$ & 13 & $\begin{array}{l}\text { Virtual (augmented) reality } \\
\text { goggles containing built-in } \\
\text { LCD screen } 2 \text { wks of twice } \\
\text { daily ( } 30 \text {-min duration) }\end{array}$ & $\begin{array}{l}\text { Same } \\
\text { procedure } \\
\text { without VR }\end{array}$ & $\begin{array}{l}\text { Gait velocity, stride } \\
\text { length, cadence, } \\
\text { and FOGQ }\end{array}$ & $\begin{array}{l}\text { Virtual device significantly } \\
\text { enhanced velocity and stride } \\
\text { length; overall improvement in } \\
\text { FOGQ }\end{array}$ \\
\hline $\begin{array}{l}\text { Espay et al, } \\
2013^{38} \\
\text { Prospective } \\
\text { cohort }\end{array}$ & $\begin{array}{l}13,2 \text { completed } \\
\text { study }\end{array}$ & $\begin{array}{l}\text { Virtual (augmented) reality } \\
\text { goggles containing built-in } \\
\text { LCD screen; } 4 \text { wks } \\
\text { at-home use }\end{array}$ & None & UPDRS3 and FOGQ & $\begin{array}{l}\text { Improved FOGQ and UPDRS3 } \\
\text { in } 1 \text { of } 2 \text { participants }\end{array}$ \\
\hline
\end{tabular}

Abbreviations: FoF, fear of falling; FoG, freezing of gait; FOGQ, Freezing of Gait Questionnaire; H\&Y, Hoehn and Yahr Scale; LCD: liquid crystal display;

MT, movement time; PD, Parkinson disease; PEDro, Physiotherapy Evidence Database score; RCT, randomized controlled trial; UPDRS3, Third part of Unified Parkinson's Disease Rating Scale; VR, virtual reality; VRG, virtual reality glasses.

ranging from 21 sessions of Nintendo Wii Fit gaming for 7 weeks to 1 session of VR headset use.

\section{Immersive VR}

There were fewer immersive VR studies and these studies had lower mean PEDro scores when compared with nonimmersive VR studies. The VR modalities in the immersive studies used a VR headset or a multisensory immersive system that included polarized glasses. All the studies showed positive improvement in primary outcomes with the exception of Ma and colleagues, which showed no difference in success rates or kinematics with moving balls, and only showed improvement in reaching for stationary balls. ${ }^{11}$ The mean number of participants in the studies was 18.4 .
All 7 studies had each participant complete tasks without VR then with the VR therapy. None of the studies compared immersive VR therapy with more conventional therapies. Robles-Garcia and colleagues compared 2 VR groups where the experimental group imitated an avatar's finger tapping in the VR system while the control group lacked this imitation. ${ }^{12}$ The authors found that adding that imitation to the VR group lead to an increase in movement amplitude.

Among the immersive VR studies, only Janeh and colleagues commented on possible adverse effects (AEs) and found that VR was a safe method without AEs of discomfort or simulator sickness. ${ }^{13}$ The other 6 studies did not make any mention or discussion of AEs related to the training. 


\section{Nonimmersive VR}

VR modalities used in nonimmersive studies included consumer video gaming systems. Nintendo Wii and Microsoft Xbox Kinect were most commonly used. Among the 21 studies, 14 compared VR therapy with a type of traditional exercise (eg, treadmill training, stretching exercises, balance training). The mean number of participants of the studies was 28.3.

Five studies showed a difference between the VR and traditional training groups. ${ }^{14-18}$ However, 9 studies showed positive improvement in both groups and found no between-group differences. ${ }^{19-25}$ Among the remaining 7 studies, all showed improvement in primary outcomes after adding VR interventional therapy. In $1 \mathrm{RCT}$, 3 groups were compared (no intervention, Nintendo Wii, and Xbox Kinect) for gait tests, anxiety levels, memory, and attention. ${ }^{26}$ The authors found that only the Nintendo Wii group showed improvement in outcomes. A prospective cohort study was the only one to compare different doses of VR therapy (10 sessions vs 15 sessions of Nintendo Wii Fit). ${ }^{27}$ The authors found that both groups demonstrated the same amount of improvement on balance performances with no group effect.

Ten studies reported no AEs during the training, but also did not define what was considered an $A E .{ }^{15,16,19,22-25,27-29 ~}$ Eight studies did not make any mention of AEs. 14,17,21,26,27,30-32 Yen and colleagues reported no AEs during training except for the patients' tendency to fall. ${ }^{20}$ However, therapists supervised the patients to avoid falls and no falls occurred. Nuic and colleagues reported 3 serious AEs, unrelated to the training: severe pneumonia $(n=1)$ and deep-brain stimulation generator replacement $(n=2) .{ }^{33}$ During the video game training sessions no specific AEs occurred. Only Pompeu and colleagues defined an $A E$ as any untoward medical occurrence such as convulsion, syncope, dizziness, vertigo, falls, or any medical condition that required hospitalization or disability. ${ }^{34}$ One researcher registered the occurrence of any $A E$; however, none occurred during the study period.

\section{DISCUSSION}

This systematic review demonstrates that VR therapy is a promising addition to rehabilitation for PD. Evidence supporting VR therapy is limited, but is continually expanding, and current evidence has shown improvement in assessments and rehabilitative outcomes involving
FIGURE PRISMA Screening and Review Process Flow Diagram

89 Records identified through database searching starting July 2019

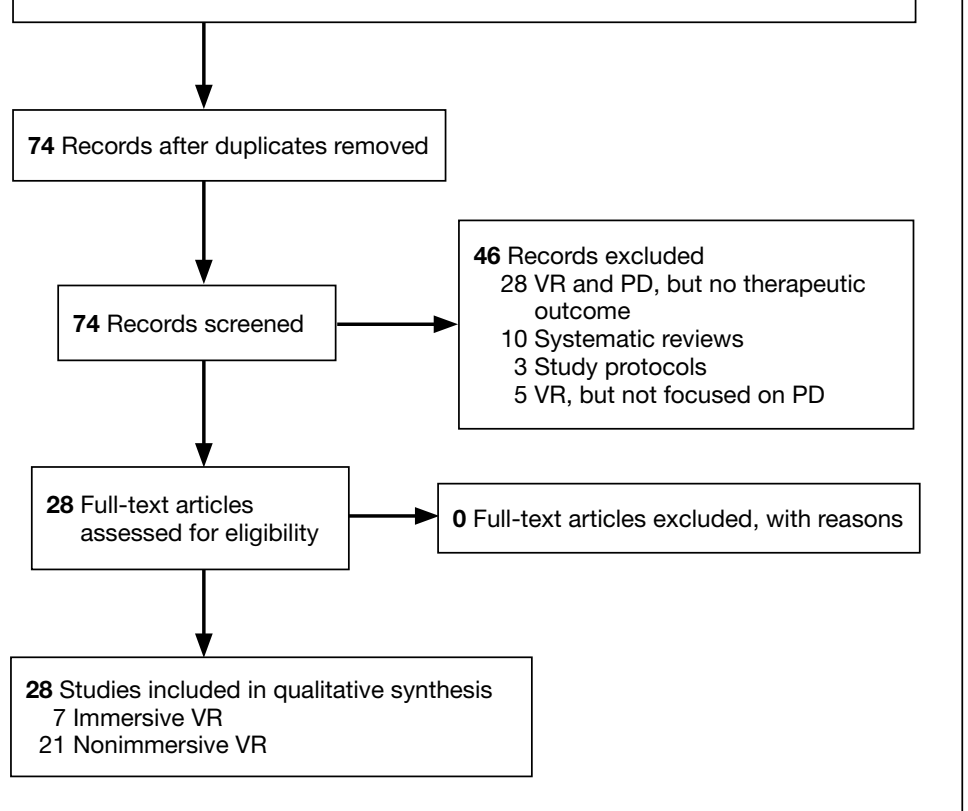

Abbreviations: PD, Parkinson disease; VR, virtual reality.

PD. Most nonimmersive studies have shown that VR therapy does not lead to better outcomes when compared with traditional therapy but also is not harmful and does provide similar improvement. Immersive VR studies, on the other hand, have not compared therapy with conventional training extensively, and tend to focus more on time for task completion or movement.

There were fewer immersive VR studies than nonimmersive VR studies. This could be because of the increased technological difficulty and demand to correctly execute immersive VR modalities, as well as the-until recently-substantial expense. This might be another reason why the mean PEDro scores for immersive VR $\mathrm{RCTs}$ were lower than the mean scores found in nonimmersive RCTs.

\section{Limitations}

This review was limited by several factors related to the included studies. A variety of rating scales were used in the immersive and nonimmersive VR studies. Although there was some general overlap with common measurements such as gait, balance, kinematics, and VR feasibility, no studies had the same primary and 
TABLE 3 Nonimmersive Virtual Reality Studies Reviewed

\begin{tabular}{|c|c|c|c|c|c|}
\hline $\begin{array}{l}\text { Source } \\
\text { Study design } \\
\text { (PEDro score) }\end{array}$ & $\begin{array}{l}\text { Participants, No. } \\
\text { (H\&Y) } \\
\text { Study Groups: No. }\end{array}$ & $\begin{array}{l}\text { VR Modality and } \\
\text { Duration }\end{array}$ & Control & Outcomes & Primary findings \\
\hline $\begin{array}{l}\text { Pelosin et al, } \\
2019^{14} \\
\text { RCT (5) }\end{array}$ & $\begin{array}{l}24(2-3) \\
15 \text { OA } \\
\text { Control: } \\
14 \text { PD + } 8 \text { OA } \\
\text { Experimental: } 10 \\
\text { PD + } 7 \text { OA }\end{array}$ & $\begin{array}{l}\text { Nonimmersive VR } \\
\text { environment with } \\
\text { treadmill training; } \\
\text { three } 45-\text { min } \\
\text { sessions/wk for } \\
6 \text { wks }\end{array}$ & $\begin{array}{l}\text { Treadmill training } \\
\text { without VR }\end{array}$ & $\begin{array}{l}\text { Primary: No. falls } \\
\text { and SAI magnitude; } \\
\text { Secondary: Gait pa- } \\
\text { rameters }\end{array}$ & $\begin{array}{l}\text { Increase in inhibition of SAI } \\
\text { protocol on cortical excit- } \\
\text { ability, improved obstacle ne- } \\
\text { gotiation performance, and } \\
\text { reduction of number of falls } \\
\text { in VR group }\end{array}$ \\
\hline $\begin{array}{l}\text { Liao et al, } 2015^{15} \\
\text { RCT (7) }\end{array}$ & $\begin{array}{l}36(1-3) \\
\text { Control: } 12 \\
\text { Traditional } \\
\text { exercise: } 12 \\
\text { VR: } 12\end{array}$ & $\begin{array}{l}\text { Wii Fit VR exercise; } \\
\text { two } 1 \text {-h sessions/wk } \\
\text { for } 6 \text { wks }\end{array}$ & $\begin{array}{l}\text { Traditional ex- } \\
\text { ercise or only } \\
\text { fall-prevention } \\
\text { education } \\
\text { (control) }\end{array}$ & $\begin{array}{l}\text { Primary: Obstacle } \\
\text { crossing perfor- } \\
\text { mance and dynamic } \\
\text { balance } \\
\text { Secondary: SOT, } \\
\text { PDQ-39, FES-I, TUG }\end{array}$ & $\begin{array}{l}\text { VR group showed greater im- } \\
\text { provement in obstacle cross- } \\
\text { ing velocity, crossing stride } \\
\text { length, dynamic balance, and } \\
\text { secondary outcomes }\end{array}$ \\
\hline $\begin{array}{l}\text { Mirelman et al, } \\
2010^{16} \\
\text { Repeated mea- } \\
\text { sures study with } \\
\text { historical control }\end{array}$ & $20(2-3)$ & $\begin{array}{l}\text { Treadmill testing with } \\
\text { virtual environment; } \\
3 \text { sessions/wk for } \\
6 \text { wks }\end{array}$ & $\begin{array}{l}\text { Historical ac- } \\
\text { tive group of PD } \\
\text { patients who fol- } \\
\text { lowed similar pro- } \\
\text { tocol without VR }\end{array}$ & $\begin{array}{l}\text { Gait measures and } \\
\text { Trail Making Test } \\
\text { times }\end{array}$ & $\begin{array}{l}\text { Gait speed significantly } \\
\text { improved overall; Trail } \\
\text { Making Test times improved }\end{array}$ \\
\hline $\begin{array}{l}\text { Lee et al, } 2015^{17} \\
\text { RCT (4) }\end{array}$ & $\begin{array}{l}20 \\
\text { Control: } 10 \\
\text { Experimental: } 10\end{array}$ & $\begin{array}{l}\text { K-Pop Dance Festival } \\
\text { for Nintendo Wii + } \\
\text { NDT and FES; } \\
\text { five } 45-\text { min } \\
\text { session/wk for } 6 \text { wks }\end{array}$ & $\begin{array}{l}\text { NDT and FES } \\
\text { without Wii }\end{array}$ & $\begin{array}{l}\text { Balance, ADLs, and } \\
\text { depressive disorder } \\
\text { status }\end{array}$ & $\begin{array}{l}\text { Significant improvement in } \\
\text { balance, ADLs, and depres- } \\
\text { sive disorder status in ex- } \\
\text { perimental group }\end{array}$ \\
\hline $\begin{array}{l}\text { Feng et al, } \\
2019^{18} \\
\text { RCT (8) }\end{array}$ & $\begin{array}{l}28(2.5-4) \\
\text { Control: } 14 \\
\text { Experimental: } 14\end{array}$ & $\begin{array}{l}\text { Standard television } \\
\text { VR device; } \\
\text { five } 45-\mathrm{min} \\
\text { sessions/wk for } 12 \text { wks }\end{array}$ & $\begin{array}{l}\text { Conventional } \\
\text { physical therapy }\end{array}$ & $\begin{array}{l}\text { BBS, TUGT, } \\
\text { UPDRS3, FGA }\end{array}$ & $\begin{array}{l}\text { Significant improvement } \\
\text { in BBS, TUGT, and FGA; } \\
\text { no significant difference in } \\
\text { UPDRS3 }\end{array}$ \\
\hline $\begin{array}{l}\text { Gandolfi et al, } \\
2017^{19} \\
\text { RCT (7) }\end{array}$ & $\begin{array}{l}76(2.5-3) \\
\text { Control: } 38 \\
\text { Experimental: } 38\end{array}$ & $\begin{array}{l}\text { Nintendo Wii Fit; } \\
\text { three } 50-\text { min } \\
\text { sessions/wk for } 7 \text { wks }\end{array}$ & SIBT & $\begin{array}{l}\text { Primary: BBS } \\
\text { Secondary: ABC } \\
\text { scale, 10-MWT, DGI, } \\
\text { PDQ-8 }\end{array}$ & $\begin{array}{l}\text { Significant improvement in } \\
\text { BBS; no significant between- } \\
\text { group differences in second- } \\
\text { ary outcomes }\end{array}$ \\
\hline $\begin{array}{l}\text { Yen et al, } 2011^{20} \\
\text { RCT ( } 7)\end{array}$ & $\begin{array}{l}42(2-3) \\
\text { Control: } 14 \\
\text { CBT: } 14 \\
\text { VR: } 14\end{array}$ & $\begin{array}{l}\text { VR-augmented bal- } \\
\text { ance training with } \\
\text { 3D VR games; two } \\
\text { to three } 30-\text { min ses- } \\
\text { sions/wk for } 6 \text { wks }\end{array}$ & Untrained or $\mathrm{CBT}$ & $\begin{array}{l}\text { Equilibrium scores, } \\
\text { sensory ratios, and } \\
\text { VRT }\end{array}$ & $\begin{array}{l}\text { No significant difference be- } \\
\text { tween VR and CBT groups; } \\
\text { equilibrium scores in VR and } \\
\text { CBT group improved com- } \\
\text { pared with control }\end{array}$ \\
\hline $\begin{array}{l}\text { Yang et al, } \\
2016^{21} \\
\text { RCT (7) }\end{array}$ & $\begin{array}{l}23(2-3) \\
\text { Control: } 12 \\
\text { Experimental: } 11\end{array}$ & $\begin{array}{l}\text { VR balance } \\
\text { training on touch- } \\
\text { screen computer; } \\
\text { two } 50 \text {-min } \\
\text { sessions/wk for } 6 \text { wks }\end{array}$ & CBT & $\begin{array}{l}\text { Primary: BBS } \\
\text { Secondary: DGI, } \\
\text { TUG, PDQ, motor } \\
\text { score of UPDRS }\end{array}$ & $\begin{array}{l}\text { Both groups performed bet- } \\
\text { ter in BBS, DGI, TUGT, PDQ, } \\
\text { without significant differ- } \\
\text { ences between groups }\end{array}$ \\
\hline $\begin{array}{l}\text { Pompeu et al, } \\
2012^{22} \\
\text { RCT (7) }\end{array}$ & $\begin{array}{l}32(1-2) \\
\text { Control: } 16 \\
\text { Experimental: } 16\end{array}$ & $\begin{array}{l}\text { Global exercise + Wii } \\
\text { Fit VR; } \\
\text { two } 1-\mathrm{h} \text { sessions/wk } \\
\text { for } 7 \text { wks }\end{array}$ & $\begin{array}{l}\text { Global exercise } \\
\text { plus balance ex- } \\
\text { ercise }\end{array}$ & $\begin{array}{l}\text { Primary: UPDRS } \\
\text { (section II) } \\
\text { Secondary: BBS }\end{array}$ & $\begin{array}{l}\text { Both groups showed } \\
\text { improvement in section II of } \\
\text { UPDRS; no additional advan- } \\
\text { tages with Wii-based training }\end{array}$ \\
\hline $\begin{array}{l}\text { Heuvel et al, } \\
2014^{23} \\
\operatorname{RCT}(7)\end{array}$ & $\begin{array}{l}33(2-3) \\
\text { Control: } 16 \\
\text { Experimental: } 17\end{array}$ & $\begin{array}{l}\text { Interactive balance } \\
\text { games with explicit } \\
\text { augmented visual } \\
\text { feedback (VFT); } \\
\text { two } 1 \text {-h sessions/wk } \\
\text { for } 5 \text { wks }\end{array}$ & $\begin{array}{l}\text { Conventional } \\
\text { training }\end{array}$ & $\begin{array}{l}\text { Primary: Functional } \\
\text { reach test } \\
\text { Secondary: Balance } \\
\text { and gait }\end{array}$ & $\begin{array}{l}\text { No significant difference } \\
\text { found in functional reach test }\end{array}$ \\
\hline $\begin{array}{l}\text { Liao et al, } 2015^{24} \\
\text { RCT (7) }\end{array}$ & $\begin{array}{l}36(1-3) \\
\text { Control: } 12 \\
\text { Traditional } \\
\text { exercise: } 12 \\
\text { VR: } 12\end{array}$ & $\begin{array}{l}\text { VR-based Wii Fit } \\
12 \text { sessions in } 6 \text { wks }\end{array}$ & $\begin{array}{l}\text { Traditional } \\
\text { exercise or only } \\
\text { fall-prevention } \\
\text { education } \\
\text { (control) }\end{array}$ & $\begin{array}{l}\text { Lower extremity } \\
\text { muscle strength, } \\
\text { sensory integration } \\
\text { ability, walking veloc- } \\
\text { ity, stride length, and } \\
\text { functional gait as- } \\
\text { sessment }\end{array}$ & $\begin{array}{l}\text { Significant improvement in } \\
\text { level walking velocity, stride } \\
\text { length, functional gait as- } \\
\text { sessment, muscle strength, } \\
\text { and vestibular integration in } \\
\text { VR and traditional exercise } \\
\text { group }\end{array}$ \\
\hline
\end{tabular}




\begin{tabular}{|c|c|c|c|c|c|}
\hline $\begin{array}{l}\text { Source } \\
\text { Study design } \\
\text { (PEDro score) }\end{array}$ & $\begin{array}{l}\text { Participants, No. } \\
\text { (H\&Y) } \\
\text { Study Groups: No. }\end{array}$ & $\begin{array}{l}\text { VR Modality and } \\
\text { Duration }\end{array}$ & Control & Outcomes & Primary findings \\
\hline $\begin{array}{l}\text { Fundaro et al, } \\
2018^{25} \\
\text { Retrospective } \\
\text { cohort }\end{array}$ & $\begin{array}{l}20(2-3) \\
\text { Control: } 10 \\
\text { Experimental: } 10\end{array}$ & $\begin{array}{l}\text { 42-inch flat screen } \\
\text { with virtual avatar in } \\
\text { virtual landscape; Five } \\
30 \text {-min sessions/wk } \\
\text { for } 4 \text { wks }\end{array}$ & $\begin{array}{l}\text { Conventional gait } \\
\text { training }\end{array}$ & $\begin{array}{l}\text { UPDRS, FIM, 10- } \\
\text { MWT }\end{array}$ & $\begin{array}{l}\text { All patients showed signifi- } \\
\text { cant improvement in UPDRS } \\
\text { and FIM scores; significantly } \\
\text { better improvement in } \\
\text { UPDRS in VR group }\end{array}$ \\
\hline $\begin{array}{l}\text { Alves et al, } \\
2019^{26} \\
\text { RCT (6) }\end{array}$ & $\begin{array}{l}27(1-3) \\
\text { Control: } 9 \\
\text { Experimental: } \\
9 \text { (Wii) and } \\
9 \text { (Kinect) }\end{array}$ & $\begin{array}{l}\text { Nintendo Wii; Xbox } \\
\text { Kinect } \\
\text { Two } 45-60 \text { min } \\
\text { sessions/wk }\end{array}$ & No intervention & $\begin{array}{l}\text { Single and dual task } \\
\text { gait tests (TUG, } \\
10 \mathrm{MWT} \text {, and 30SWT), } \\
\text { anxiety levels, mem- } \\
\text { ory, and attention }\end{array}$ & $\begin{array}{l}\text { Only Wii group showed } \\
\text { significant improvement in } \\
\text { single and dual task gait } \\
\text { tests, decreased anxiety, } \\
\text { and improved memory and } \\
\text { attention }\end{array}$ \\
\hline $\begin{array}{l}\text { Negrini et al, } \\
2016^{27} \\
\text { Prospective } \\
\text { cohort }\end{array}$ & $\begin{array}{l}27 \\
\text { Control: } 11 \\
\text { Experimental: } 16\end{array}$ & $\begin{array}{l}\text { Nintendo Wii Fit } \\
\text { three } 30-\text { min } \\
\text { sessions/wk for } 5 \text { wks }\end{array}$ & $\begin{array}{l}\text { Nintendo Wii Fit } \\
\text { two } 30-\text { min } \\
\text { sessions/wk for } \\
5 \text { wks }\end{array}$ & $\begin{array}{l}\text { FRT, PST, BBS, and } \\
\text { Tinetti scale }\end{array}$ & $\begin{array}{l}\text { Both groups showed } \\
\text { significant improvement on } \\
\text { balance performances }\end{array}$ \\
\hline $\begin{array}{l}\text { van Beek et al, } \\
2019^{28} \\
\text { Pre/post pilot }\end{array}$ & $10(2-4)$ & $\begin{array}{l}\text { Exergaming system } \\
\text { (Leap Motion } \\
\text { Controller) } \\
\text { Two } 30-\text { min sessions/ } \\
\text { wk for } 4 \text { wks }\end{array}$ & N/A & $\begin{array}{l}\text { Primary: Feasibility } \\
\text { and usability (SUS } \\
\text { and PRPS) } \\
\text { Secondary: 9HPT, } \\
\text { DexQ-24, PDQ-39, } \\
\text { UPDRS) }\end{array}$ & $\begin{array}{l}\text { Significant improvement in } \\
\text { PRPS; those with impaired } \\
\text { dexterity had significant } \\
\text { improvement in 9HPT and } \\
\text { PDQ-39 }\end{array}$ \\
\hline $\begin{array}{l}\text { Palacios-Navarro } \\
\text { et al, } 2015^{29} \\
\text { Pre-post } \\
\text { prospective }\end{array}$ & 7 & $\begin{array}{l}\text { Microsoft Kinect; } \\
4 \text { sessions/wk for } \\
5 \text { wks }\end{array}$ & N/A & $\begin{array}{l}\text { Completion time } \\
\text { score and 10MWT }\end{array}$ & $\begin{array}{l}\text { Significant improvement in } \\
\text { completion time score and } \\
\text { 10MWT }\end{array}$ \\
\hline $\begin{array}{l}\text { Mendes et al, } \\
2012^{30} \\
\text { Non-RCT }\end{array}$ & $\begin{array}{l}16(1-2) \\
\text { Control: } 11 \text { healthy } \\
\text { older people }\end{array}$ & $\begin{array}{l}\text { Nintendo Wii; } 10 \\
\text { games } \\
2 \text { sessions/wk for } \\
7 \text { wks }\end{array}$ & $\begin{array}{l}\text { Healthy older } \\
\text { people }\end{array}$ & $\begin{array}{l}\text { Scores of } 10 \text { Wii Fit } \\
\text { games and } \\
\text { functional reach test }\end{array}$ & $\begin{array}{l}\text { Scores of PD group depends } \\
\text { on demands of games } \\
\text { involved; significant improve- } \\
\text { ment in functional reach test } \\
\text { posttraining }\end{array}$ \\
\hline $\begin{array}{l}\text { Lameira de Melo } \\
\text { et al, } 2018^{31} \\
\text { RCT (7) }\end{array}$ & $\begin{array}{l}37(1-3) \\
\text { Control: } 12 \\
\text { Treadmill: } 13 \\
\text { VR: } 12\end{array}$ & $\begin{array}{l}\text { Kinect Xbox } 360 \text {; } \\
\text { Three 20-min } \\
\text { sessions/wk for } 4 \text { wks }\end{array}$ & $\begin{array}{l}\text { Conventional train- } \\
\text { ing (control) and } \\
\text { treadmill training; } \\
\text { Three } 20 \text {-min ses- } \\
\text { sions/wk for } 4 \text { wks }\end{array}$ & $\begin{array}{l}\text { Clinical measures, } \\
\text { gait variables, and } \\
\text { 6MWT }\end{array}$ & $\begin{array}{l}\text { Longer distance on 6MWT } \\
\text { and faster gait speed in VR } \\
\text { and treadmill groups; VR } \\
\text { group had more intense } \\
\text { heart rate }\end{array}$ \\
\hline $\begin{array}{l}\text { Maidan et al, } \\
2018^{32} \\
\text { RCT (4) }\end{array}$ & $\begin{array}{l}64(2-3) \\
\text { Control: } 34 \\
\text { Intervention: } 30\end{array}$ & $\begin{array}{l}\text { Treadmill training with } \\
\text { virtual obstacles on } \\
\text { screen in front of tread- } \\
\text { mill; Three } 45-\text { min ses- } \\
\text { sions/wk for } 6 \text { wks }\end{array}$ & $\begin{array}{l}\text { Treadmill train- } \\
\text { ing; Three 45-min } \\
\text { sessions/wk for } \\
6 \text { wks }\end{array}$ & Prefrontal activation & $\begin{array}{l}\text { Significant reduction in } \\
\text { prefrontal activation in both } \\
\text { groups, greater decrease in } \\
\text { interventional }\end{array}$ \\
\hline $\begin{array}{l}\text { Nuic et al, } 2018^{33} \\
\text { Pre/post pilot }\end{array}$ & $10(\geq 3)$ & $\begin{array}{l}\text { Kinect motion sensor } \\
18 \text { sessions over } 6 \text { or } \\
9 \text { wks }\end{array}$ & N/A & $\begin{array}{l}\text { Feasibility and } \\
\text { acceptability of video } \\
\text { game rehabilitation } \\
\text { and its effects on } \\
\text { parkinsonian disabil- } \\
\text { ity, gait, and balance } \\
\text { disorders }\end{array}$ & $\begin{array}{l}\text { High feasibility, acceptability, } \\
\text { and satisfaction scores; } \\
\text { FOGQ, GABS, and axial } \\
\text { score significantly decreased } \\
\text { and ABC-scale increased }\end{array}$ \\
\hline $\begin{array}{l}\text { Pompeu et al, } \\
2013^{34} \\
\text { Pre/post } \\
\text { prospective }\end{array}$ & $7(2-3)$ & $\begin{array}{l}\text { Kinect Adventures } \\
\text { Fourteen 1-h ses- } \\
\text { sions, } 3 \text { sessions/wk }\end{array}$ & N/A & $\begin{array}{l}\text { Feasibility and } \\
\text { safety outcomes, } \\
\text { 6MWT, BESTest, } \\
\text { DGI, } \\
\text { PDQ-36 }\end{array}$ & $\begin{array}{l}\text { Improvement in game scores } \\
\text { and no adverse events; im- } \\
\text { provements seen in 6MWT, } \\
\text { BESTest, DGI, and PDQ-39 }\end{array}$ \\
\hline
\end{tabular}

Abbreviations: 6MWT, 6-minute walk test; 9HPT, Nine-Hole Peg Test; 10MWT, 10-Meter Walk Test; 30SWT, 30-Seconds Walk Test; ABC, activity balance confidence; ADLs, activities of daily living; BBS, Berg Balance Scale; BESTest, Balance Evaluation System Test; CBT, conventional balance training; DexQ24, Dexterity Questionnaire-24; DGI, Dynamic Gait Index; FES-I, fall efficacy scale; FES, functional electrical stimulation; FGA, Functional Gait Assessment; FOGQ, Freezing of Gait Questionnaire; GABS, gait and balance scale; H\&Y, Hoehn and Yahr; MDS-UPDRS, Movement Disorders Society Unified Parkinson's Disease Rating Scale; N/A, not applicable; NDT, neurodevelopment treatment; PD, Parkinson's disease; PDQ, Parkinson's Disease Questionnaire; PEDro, Physiotherapy Evidence Database score; PRPS, Pittsburgh Rehabilitation Participation Scale; RCT, randomized controlled trial; SAI, short-latency afferent inhibition; SIBT, sensory integration balance training; SOT, sensory organization test; SYS, System Usability Scale; TUGT, Timed Up and Go Test; UPDRS, Unified Parkinson's Disease Rating Scale; VR, virtual reality; VRT, verbal reaction time. 
secondary outcomes. Such heterogeneity in protocols and outcomes limited our ability to draw conclusions from these differing studies. Additionally, the average number of participants of both immersive and nonimmersive studies were small and the statistical significance of findings should be interpreted with caution. Finally, VR devices and systems differed between studies, further limiting comparisons. Although these factors limit this systematic review, we can still identify treatment and research implications. Adequately powered future studies with standardized protocols would further improve the available evidence and support for VR as an intervention.

\section{CONCLUSIONS}

VR therapy is a promising rehabilitation modality for PD. Additional investigations of VR therapy and PD should include direct comparisons between immersive and nonimmersive VR therapies. It could be hypothesized that the greater immersion and engagement potential of immersive VR would demonstrate greater functional improvement compared with nonimmersive VR, but there is no data to support this for PD. VR therapy for PD appears to be a relatively safe alternative or adjunct to traditional therapy with a potentially positive impact on a variety of symptoms and is growing as an innovative therapeutic approach for PD patients.

\section{Author affiliations}

Brian Chau is a Diplomat of Physical Medicine and Rehabilitation and Sarah Humbert is an Attending Physician, both at the US Department of Veteran Affairs Loma Linda Healthcare System. Sarah Humbert is a Diplomat of Physical Medicine and Rehabilitation, a Diplomat of Neuromuscular Medicine, and an Assistant Professor; Brian Chau is an Assistant Professor of Physical Medicine and Rehabilitation; and Aaron Shou was a Medical Student at the time the article was written and is now a Resident Physician in Physical Medicine and Rehabilitation; all at Loma Linda University School of Medicine in California .

\section{Author disclosures}

The authors report no actual or potential conflicts of interest with regard to this article.

\section{Disclaimer}

The opinions expressed herein are those of the authors and do not necessarily reflect those of Federal Practitioner, Frontline Medical Communications Inc., the US Government, or any of its agencies.

\section{References}

1. de Lau LM, Breteler MM. Epidemiology of Parkinson's disease. Lancet Neurol. 2006;5(6):525-535. doi:10.1016/S1474-4422(06)70471-9

2. Alves G, Forsaa EB, Pedersen KF, Dreetz Gjerstad M, Larsen JP. Epidemiology of Parkinson's disease. J Neurol. 2008;255 Suppl 5:18-32. doi:10.1007/s00415-008-5004-3

3. US Department of Veterans Affairs. Parkinson's Disease
Research, Education and Clinical Centers. Updated March 4, 2021. Accessed March 5, 2021. https://www .parkinsons.va.gov/index.asp.

4. Raza C, Anjum R, Shakeel NUA. Parkinson's disease: mechanisms, translational models and management strategies. Life Sci. 2019;226:77-90. doi:10.1016/j.lfs.2019.03.057

5. Landers MR, Navalta JW, Murtishaw AS, Kinney JW, Pirio Richardson S. A high-intensity exercise boot camp for persons with Parkinson disease: a phase ii, pragmatic, randomized clinical trial of feasibility, safety, signal of efficacy, and disease mechanisms. J Neurol Phys Ther. 2019;43(1):12-25. doi:10.1097/NPT.0000000000000249

6. Ebersbach G, Ebersbach A, Edler D, et al. Comparing exercise in Parkinson's disease--the Berlin LSVT®BIG study [published correction appears in Mov Disord. 2010 Oct 30;25(14):2478]. Mov Disord. 2010;25(12):1902-1908. doi:10.1002/mds.23212

7. Abbruzzese G, Marchese R, Avanzino L, Pelosin E. Rehabilitation for Parkinson's disease: current outlook and future challenges. Parkinsonism Relat Disord. 2016;22(suppl 1):S60-S64. doi:10.1016/j.parkreldis.2015.09.005

8. Weiss PL, Katz N. The potential of virtual reality for rehabilitation. J Rehabil Res Dev. 2004;41(5):vii-x.

9. da Costa BR, Hilfiker R, Egger M. PEDro's bias: summary quality scores should not be used in metaanalysis. J Clin Epidemiol. 2013;66(1):75-77. doi:10.1016/j.jclinepi.2012.08.003

10. Moher D, Liberati A, Tetzlaff J, Altman DG; PRISMA Group. Preferred reporting items for systematic reviews and meta-analyses: the PRISMA statement. PLoS Med. 2009;6(7):e1000097. doi:10.1371/journal.pmed.1000097

11. Ma HI, Hwang WJ, Fang JJ, et al. Effects of virtual reality training on functional reaching movements in people with Parkinson's disease: a randomized controlled pilot trial. Clin Rehabil. 2011;25(10):892-902. doi:10.1177/0269215511406757

12. Robles-García V, Corral-Bergantiños $Y$, Espinosa N, et al. Effects of movement imitation training in Parkinson's disease: a virtual reality pilot study. Parkinsonism Relat Disord. 2016;26:17-23. doi:10.1016/j.parkreldis.2016.02.022

13. Janeh $O$, Fründt $O$, Schönwald $B$, et al. Gait Training in virtual reality: short-term effects of different virtual manipulation techniques in Parkinson's Disease. Cells. 2019;8(5):419. Published 2019 May 6. doi:10.3390/cells8050419

14. Pelosin E, Cerulli C, Ogliastro C, et al. A multimodal training modulates short afferent inhibition and improves complex walking in a cohort of faller older adults with an increased prevalence of Parkinson's disease. $J$ Gerontol A Biol Sci Med Sci. 2020;75(4):722-728. doi:10.1093/gerona/glz072

15. Liao YY, Yang YR, Cheng SJ, Wu YR, Fuh JL, Wang RY. Virtual reality-based training to improve obstacle-crossing performance and dynamic balance in patients with Parkinson's disease. Neurorehabil Neural Repair. 2015;29(7):658667. doi:10.1177/1545968314562111

16. Mirelman A, Maidan I, Herman T, Deutsch JE, Giladi N, Hausdorff JM. Virtual reality for gait training: can it induce motor learning to enhance complex walking and reduce fall risk in patients with Parkinson's disease?. J Gerontol A Biol Sci Med Sci. 2011;66(2):234-240. doi:10.1093/gerona/glq201

17. Lee NY, Lee DK, Song HS. Effect of virtual reality dance exercise on the balance, activities of daily living, and depressive disorder status of Parkinson's disease patients. J Phys Ther Sci. 2015;27(1):145-147. doi:10.1589/ jpts.27.145

18. Feng $\mathrm{H}$, Li C, Liu J, et al. Virtual reality rehabilitation versus conventional physical therapy for improving balance and gait in Parkinson's disease patients: a randomized controlled trial. Med Sci Monit. 2019;25:4186-4192. Published 2019 Jun 5. doi:10.12659/MSM.916455

19. Gandolfi M, Geroin C, Dimitrova E, et al. Virtual real- 
ity telerehabilitation for postural instability in Parkinson's disease: a multicenter, single-blind, randomized, controlled trial. Biomed Res Int. 2017;2017:7962826. doi:10.1155/2017/7962826

20. Yen $\mathrm{CY}$, Lin $\mathrm{KH}, \mathrm{Hu} \mathrm{MH}$, Wu RM, Lu TW, Lin CH. Effects of virtual reality-augmented balance training on sensory organization and attentional demand for postural control in people with Parkinson disease: a randomized controlled trial. Phys Ther. 2011;91(6):862-874. doi:10.2522/ptj.20100050

21. Yang WC, Wang HK, Wu RM, Lo CS, Lin KH. Homebased virtual reality balance training and conventional balance training in Parkinson's disease: a randomized controlled trial. J Formos Med Assoc. 2016;115(9):734-743. doi:10.1016/j.jfma.2015.07.012

22. Pompeu JE, Mendes FA, Silva KG, et al. Effect of Nintendo WiiTM-based motor and cognitive training on activities of daily living in patients with Parkinson's disease: a randomised clinical trial. Physiotherapy. 2012;98(3):196-204. doi:10.1016/j.physio.2012.06.004

23. van den Heuvel MR, Kwakkel G, Beek PJ, Berendse HW, Daffertshofer A, van Wegen EE. Effects of augmented visual feedback during balance training in Parkinson's disease: a pilot randomized clinical trial. Parkinsonism Relat Disord. 2014;20(12):1352-1358. doi:10.1016/j.parkreldis.2014.09.022

24. Liao YY, Yang YR, Cheng SJ, Wu YR, Fuh JL, Wang RY. Virtual reality-based training to improve obstacle-crossing performance and dynamic balance in patients with Parkinson's disease. Neurorehabil Neural Repair. 2015;29(7):658667. doi:10.1177/1545968314562111

25. Fundarò C, Maestri R, Ferriero G, Chimento P, Taveggia G, Casale R. Self-selected speed gait training in Parkinson's disease: robot-assisted gait training with virtual reality versus gait training on the ground. Eur J Phys Rehabil Med. 2019;55(4):456-462. doi:10.23736/S1973-9087.18.05368-6

26. Alves MLM, Mesquita BS, Morais WS, Leal JC, Satler CE, Dos Santos Mendes FA. Nintendo Wii TM versus Xbox Kinect ${ }^{\mathrm{TM}}$ for assisting people with Parkinson's disease. Percept Mot Skills. 2018;125(3):546-565. doi:10.1177/0031512518769204

27. Negrini S, Bissolotti L, Ferraris A, Noro F, Bishop MD, Villafañe JH. Nintendo Wii Fit for balance rehabilitation in patients with Parkinson's disease: A comparative study. J Bodyw Mov Ther. 2017;21(1):117-123. doi:10.1016/j.jbmt.2016.06.001

28. van Beek JJW, van Wegen EEH, Bohlhalter S, Vanbellingen T. Exergaming-based dexterity training in persons with Parkinson disease: a pilot feasibility study. J Neurol Phys Ther.
2019;43(3):168-174. doi:10.1097/NPT.0000000000000278

29. Palacios-Navarro G, García-Magariño I, Ramos-Lorente P. A kinect-based system for lower limb rehabilitation in Parkinson's disease patients: a pilot study. J Med Syst. 2015;39(9):103. doi:10.1007/s10916-015-0289-0

30. dos Santos Mendes FA, Pompeu JE, Modenesi Lobo A, et al. Motor learning, retention and transfer after virtual-reality-based training in Parkinson's disease--effect of motor and cognitive demands of games: a longitudinal, controlled clinical study. Physiotherapy. 2012;98(3):217-223. doi:10.1016/.jphysio.2012.06.001

31. de Melo GEL, Kleiner AFR, Lopes JBP, et al. Effect of virtual reality training on walking distance and physical fitness in individuals with Parkinson's disease. Neuro Rehabilitation. 2018;42(4):473-480. doi:10.3233/NRE-172355

32. Maidan I, Nieuwhof F, Bernad-Elazari H, et al. Evidence for differential effects of 2 forms of exercise on prefrontal plasticity during walking in Parkinson's disease. Neurorehabil Neural Repair. 2018;32(3):200-208. doi:10.1177/1545968318763750

33. Nuic D, Vinti M, Karachi C, Foulon P, Van Hamme A, Welter ML. The feasibility and positive effects of a customised videogame rehabilitation programme for freezing of gait and falls in Parkinson's disease patients: a pilot study. $J$ Neuroeng Rehabil. 2018;15(1):31. Published 2018 Apr 10. doi:10.1186/s12984-018-0375-x

34. Pompeu JE, Arduini LA, Botelho AR, et al. Feasibility, safety and outcomes of playing $\mathrm{Ki}$ nect Adventures! TM for people with Parkinson's disease: a pilot study. Physiotherapy. 2014;100(2):162-168. doi:10.1016/j.physio.2013.10.003

35. Ma HI, Hwang WJ, Wang CY, Fang JJ, Leong IF, Wang TY. Trunk-arm coordination in reaching for moving targets in people with Parkinson's disease: comparison between virtual and physical reality. Hum Mov Sci. 2012;31(5):13401352. doi:10.1016/j.humov.2011.11.004

36. Griffin HJ, Greenlaw R, Limousin P, Bhatia K, Quinn NP, Jahanshahi $M$. The effect of real and virtual visual cues on walking in Parkinson's disease. J Neurol. 2011;258(6):9911000. doi:10.1007/s00415-010-5866-z

37. Espay AJ, Baram Y, Dwivedi AK, et al. At-home training with closed-loop augmented-reality cueing device for improving gait in patients with Parkinson disease. J Rehabil Res Dev. 2010;47(6):573-581. doi:10.1682/jrrd.2009.10.0165

38. Espay AJ, Gaines L, Gupta R. Sensory feedback in Parkinson's disease patients with "on"-predominant freezing of gait. Front Neurol. 2013;4:14. Published 2013 Feb 25. doi:10.3389/fneur.2013.00014 